\title{
HERBICIDAL POTENTIAL OF Drechslera SPP. CULTURE FILTRATES AGAINST Parthenium hysterophorus L.
}

\author{
Arshad Javaid $^{1 *}$, Amna Javaid ${ }^{1}$, and Muhammad Akbar ${ }^{1}$
}

Herbicidal activity of culture filtrates of four Drechslera spp., namely D. australiensis (Bugnic.) Subram. \& B.L. Jain, D. biseptata (Sacc. \& Roum.) M.J. Richardson \& E.M. Fraser, D. hawaiiensis Bugnic. ex M.B. Ellis, and D. holmii (Luttr.) Subram. \& P.C. Jain, prepared in malt extract broth was investigated against parthenium weed (Parthenium hysterophorus L.) in both laboratory bioassays and pots. In laboratory bioassays, the effect of original (100\%) and diluted (50\%) culture filtrates of the four Drechslera spp. was studied on parthenium germination and seedling growth in $90 \mathrm{~mm}$ diameter Petri plates. Original culture filtrate of all the four Drechslera species significantly reduced germination, shoot length, shoot fresh biomass, root length, and root fresh biomass of parthenium seedlings by 43 to $77 \%, 77$ to $82 \%, 69$ to $82 \%, 90$ to $92 \%$, and 67 to $83 \%$, respectively, as compared to the control. In pot trials, foliar application of original fungal culture filtrates was carried out on 1-wk and 2-wk old parthenium seedlings. Culture filtrates of all the four Drechslera spp., except D. holmii, markedly reduced parthenium shoot dry weight. Two-week-old plants were more susceptible to foliar spray than the 1-wk old plants. There was a 13 to $55 \%$ and 28 to $65 \%$ reduction in shoot dry weight of 1-wk and 2-wk old parthenium plants respectively, due to culture filtrates of various Drechslera spp. The present study concludes that Drechslera spp. culture filtrates can be used as alternative herbicides for parthenium weed management.

Key words: Drechslera spp., fungal culture filtrates, natural herbicides, Parthenium hysterophorus.

$P$ arthenium hysterophorus L. (Asteraceae) is one of the world's worst weeds for agriculture, the environment, and human health. It is native to the subtropics of North and South America, and it was accidentally introduced to the Indian sub-continent in the mid-1950s through wheat grains (Chandras and Vartak, 1970). It is notorious for its strong competitiveness for soil moisture and nutrients, the hazards that it poses to humans and animals, and its allelopathic effect against the associated plant species (More et al., 1982; Singh et al., 2005). In Pakistan, it appeared in the late 1980s and has presently invaded and become the dominant weed in most of the waste and grazing lands, mainly in the rain-fed districts of Central and Northern Punjab, Khyber Pakhtoon Khawa, and Kashmir (Javaid and Anjum, 2005; Javaid and Riaz, 2007; Riaz and Javaid, 2010).

Some synthetic chemical herbicides, such as chlorimuron ethyl, glyphosate, atrazine, ametryn, bromoxynil, and metasulfuron, are known to be very effective in controlling this weed (Mishra and Bhan, 1994; Javaid, 2007). However, for more sustainable and eco-friendly integrated weed management strategies, there is a growing trend toward alternatives to synthetic chemical herbicides that are less pesticide-dependent or based on naturally occurring compounds (Singh et al.,

${ }^{1}$ University of the Punjab, Institute of Agricultural Sciences, Quaid-eAzam Campus, Lahore 54590 Pakistan.

"Corresponding author (arshadjpk@yahoo.com).

Received: 19 March 2011.

Accepted: 25 June 2011.
2003). One such alternative weed management strategy is using natural herbicides from plants (Javaid et al., 2010; 2011) and fungi (Javaid and Adrees, 2009; Javaid, 2010; Javaid and Ali, 2011a).

There are many examples of fungal products with herbicidal activities in the literature. Cornexistin is a nonadride phytotoxin from the coprophyllic basidiomycetous fungus, Paecilomyces variotii, which has good herbicidal activity against monocotyledonous and dicotyledonous weeds, but not against the maize crop (Nakajima et al., 1989). AAL-toxin, a phytotoxin produced by Alternaria alternata, is active against many weed species (Abbas et al., 1995). Similarly, a phytotoxic metabolite, trans-4 aminoproline, was isolated from Ascochyta caulina culture filtrates and found to be very effective in controlling Chenopodium album (Evidente et al., 2000). Drechslera is a genus of fungi in which many of the species are plant pathogens. Drechslera species have been mostly isolated from wheat, rice, barley, and maize seeds and are known to cause leaf spot, southern leaf spot, seedling blight, foot rot, leaf blotch, stem spot, leaf streak, and blight (Neergaard, 1977; Rabbani et al., 2011). Earlier studies showed that certain Drechslera species, such as $D$. maydis, D. sorghicola, D. avenae, and D. siccans, produce herbicidal metabolites (Sugawara et al., 1987; Kastanias and Tokousbalides, 2000; Evidente et al., 2005). However, there is a lack of studies regarding the herbicidal activity of Drechslera species from Pakistan. The present study was therefore conducted to explore the herbicidal potential of four Drechslera species from Pakistan, namely $D$. 
australiensis, D. biseptata, D. hawaiiensis, and D. holmii for parthenium weed management.

\section{MATERIALS AND METHODS}

\section{Preparation of test fungi culture filtrates}

Pure cultures of four species of Drechslera, viz. D. australiensis (Bugnic.) Subram. \& B.L. Jain, D. biseptata (Sacc. \& Roum.) M.J. Richardson \& E.M. Fraser, D. hawaiiensis Bugnic. ex M.B. Ellis, and D. holmii (Luttr.) Subram. \& P.C. Jain were procured from the Fungal Culture Bank, Institute of Agricultural Sciences, University of the Punjab, Lahore, Pakistan. These cultures were maintained on malt extract agar (MEA) medium and stored at $4{ }^{\circ} \mathrm{C}$.

Malt extract broth $(2 \%)$ was autoclaved at $121{ }^{\circ} \mathrm{C}$ in $250 \mathrm{~mL}$ conical flasks with $100 \mathrm{~mL}$ medium in each flask. Flasks were inoculated with $5 \mathrm{~mm}$ agar discs of each test fungal species from margins of actively growing 7-d old fungal colonies. After inoculation, flasks were incubated under static conditions at $25{ }^{\circ} \mathrm{C}$ for $4 \mathrm{wk}$. The cultures were filtered after $4 \mathrm{wk}$ through sterilized muslin cloth followed by Whatman filter paper $\mathrm{N}^{\circ} 1$ and bacterial filter papers, respectively. These filtrates were preserved at $4{ }^{\circ} \mathrm{C}$ to avoid any contamination or chemical alteration, and the culture filtrates were used within $1 \mathrm{wk}$ of filtration (Javaid and Adrees, 2009).

\section{Laboratory bioassays}

Parthenium seeds were collected in early February and the experiment was conducted in February 2009. Parthenium seeds were placed in $9 \mathrm{~cm}$ diameter sterilized Petri plates with sterilized filter papers moistened with 3 $\mathrm{mL}$ of each of the original (100\%) and diluted (50\%) crude fungal extracts of different Drechslera species. Twenty seeds were placed in each plate. The negative control treatment received $3 \mathrm{~mL}$ of sterilized distilled water. Since fungal metabolites were obtained with $2 \%$ malt extract broth and filtrates were also employed as $50 \%$ dilutions, two positive control treatments with $3 \mathrm{~mL}$ of $2 \%$ and the same quantity of $1 \%$ autoclaved malt extract broth were also included. Each treatment was replicated four times. The Petri plates were arranged in a completely randomized design in a growth room at room temperature $\left(22 \pm 2{ }^{\circ} \mathrm{C}\right)$ and 10 -h daily light period. Harvest took place after 2 wk. Data regarding germination, root/shoot length, and fresh weight were recorded (Javaid and Adrees, 2009).

\section{Pot trials}

A pot experiment was conducted during February-March 2009 in University of the Punjab, Lahore $\left(31.57^{\circ} \mathrm{N}\right.$, $74.31^{\circ} \mathrm{E}$ ), Pakistan. Plastic pots, $8 \mathrm{~cm}$ diameter and $12 \mathrm{~cm}$ deep, were filled with $350 \mathrm{~g}$ sandy loam soil with organic matter $0.69 \%$, pH 7.8, $\mathrm{N} 0.035 \%$, available $\mathrm{P} 6.3 \mathrm{mg} \mathrm{kg}^{-1}$, and available $\mathrm{K} 100 \mathrm{mg} \mathrm{kg}^{-1}$. The micronutrients $\mathrm{B}, \mathrm{Mn}$,
$\mathrm{Fe}, \mathrm{Cu}$, and $\mathrm{Zn}$ were $1.06,22.8,10.8,1.9$, and $1.3 \mathrm{mg}$ $\mathrm{kg}^{-1}$ soil, respectively. Ten parthenium seeds were sown in each pot. After germination, six seedlings per pot were maintained and the pots were divided into two groups to perform foliar spray on 1-wk and 2-wk old seedlings. All the pots were arranged in a completely randomized design in the open under natural environmental conditions. The mean minimum and maximum temperatures during the experimental period were 16 and $27^{\circ} \mathrm{C}$, respectively, and the mean relative humidity was $56 \%$. Pots were irrigated with tap water when required.

Original culture filtrates of the four selected Drechslera species were sprayed on 1-wk and 2-wk old parthenium seedlings with a hand sprayer. Each pot was sprayed with $1 \mathrm{~mL}$ of the filtrates. Both groups were sprayed three times at 5-d intervals. Control treatment plants were sprayed with distilled water. Each treatment was replicated three times. After $40 \mathrm{~d}$ of growth, plants were carefully uprooted and washed under tap water. Roots were separated from the shoots. Data regarding shoot and root length and dry biomass were recorded (Javaid and Ali, 2011b).

\section{Statistical analysis}

All data were subjected to ANOVA followed by Duncan's Multiple Range Test $(\mathrm{P} \leq 0.05)$ to separate mean differences (Steel and Torrie, 1980).

\section{RESULTS AND DISCUSSION}

\section{Laboratory bioassays}

Both the original and diluted growth medium did not have a significant effect on parthenium seed germination. Original (100\%) culture filtrates of all the four Drechslera species significantly reduced seed germination. Culture filtrates of $D$. australiensis were the most effective followed by $D$. hawaiiensis, $D$. holmii, and $D$. biseptata filtrates resulting in a $77,47,45$, and $43 \%$ reduction in germination compared to the control, respectively. The effect of diluted $(50 \%) D$. australiensis and D. biseptata culture filtrates was also significant with a 31 and $21 \%$ reduction in germination, respectively, as compared to the control (Table 1). Similar herbicidal activity of culture filtrates of other fungal species, namely Alternaria alternata, Drechslera rostrata, Fusarium solani, Trichoderma harzianum, T. viride, and T. pseudokoningii, have also been reported against seed germination of parthenium and other weed species (Javaid and Adrees, 2009; Javaid and Ali, 2011a; 2011b).

Shoot length did not show a significant response to diluted growth medium, while original growth medium significantly reduced this growth parameter by $16 \%$ over the control. All the fungal culture filtrate treatments significantly suppressed shoot length. There was a 65 to $76 \%$ and 77 to $82 \%$ reduction in shoot length over the control due to diluted and original culture filtrates of different fungal species, respectively. The effect of either of the two concentrations of growth medium 
Table 1. Effect of four Drechslera species culture filtrates on germination and growth of parthenium in laboratory bioassays.

\begin{tabular}{|c|c|c|c|c|c|c|}
\hline $\begin{array}{l}\text { Fungal } \\
\text { species }\end{array}$ & $\begin{array}{l}\text { Concen- } \\
\text { tration }\end{array}$ & $\begin{array}{l}\text { Germi- } \\
\text { nation }\end{array}$ & $\begin{array}{l}\text { Shoot } \\
\text { length }\end{array}$ & $\begin{array}{l}\text { Shoot } \\
\text { fresh } \\
\text { weight }\end{array}$ & $\begin{array}{l}\text { Root } \\
\text { length }\end{array}$ & $\begin{array}{l}\text { Root } \\
\text { fresh } \\
\text { weight }\end{array}$ \\
\hline & $-\%$ & $\longrightarrow$ & $\mathrm{mm}$ & $\mathrm{mg}$ & $\mathrm{mm}$ & $\mathrm{mg}$ \\
\hline Control & 0 & $100 \mathrm{a}$ & 9.1a & $2.9 \mathrm{a}$ & $13.4 \mathrm{a}$ & $0.95 \mathrm{a}$ \\
\hline \multirow[t]{2}{*}{ Growth medium } & 50 & $94 a$ & $8.9 \mathrm{a}$ & $2.7 \mathrm{a}$ & $10.2 b$ & $0.85 \mathrm{ab}$ \\
\hline & 100 & $90 \mathrm{ab}$ & $7.6 \mathrm{~b}$ & $2.6 \mathrm{a}$ & $9.3 \mathrm{~b}$ & $0.82 \mathrm{ab}$ \\
\hline \multirow[t]{2}{*}{ D. australiensis } & 50 & $69 \mathrm{~cd}$ & $2.2 \mathrm{~d}$ & $0.9 \mathrm{de}$ & $1.3 \mathrm{c}$ & $0.41 \mathrm{de}$ \\
\hline & 100 & $23 f$ & $1.7 \mathrm{~d}$ & $0.6 \mathrm{de}$ & $1.0 \mathrm{c}$ & $0.21 \mathrm{ef}$ \\
\hline \multirow[t]{2}{*}{ D. biseptata } & 50 & $79 b c$ & $3.2 \mathrm{c}$ & $1.5 \mathrm{bc}$ & $2.1 \mathrm{c}$ & $0.65 \mathrm{bc}$ \\
\hline & 100 & $57 \mathrm{de}$ & $2.0 \mathrm{~d}$ & $0.9 \mathrm{de}$ & $1.3 \mathrm{c}$ & $0.31 \mathrm{~d}-\mathrm{f}$ \\
\hline \multirow[t]{2}{*}{ D. hawaiiensis } & 50 & $88 \mathrm{ab}$ & $3.2 \mathrm{c}$ & $1.9 \mathrm{~b}$ & $1.8 \mathrm{c}$ & $0.47 \mathrm{~cd}$ \\
\hline & 100 & $53 \mathrm{e}$ & $1.6 \mathrm{~d}$ & $0.7 \mathrm{de}$ & $1.1 \mathrm{c}$ & $0.16 \mathrm{f}$ \\
\hline \multirow[t]{2}{*}{ D. holmii } & 50 & $89 a b$ & $2.5 \mathrm{~cd}$ & $1.2 \mathrm{~cd}$ & $1.9 \mathrm{c}$ & $0.40 \mathrm{de}$ \\
\hline & 100 & $55 \mathrm{e}$ & $2.1 \mathrm{~d}$ & $0.5 \mathrm{e}$ & $1.3 \mathrm{c}$ & $0.31 \mathrm{~d}-\mathrm{f}$ \\
\hline
\end{tabular}

Different letters in a column show a difference $(\mathrm{P} \leq 0.05)$ according to Duncan's Multiple Range Test.

Note: $100 \%$ means original fungal culture filtrates.

was not significant on shoot fresh weight. However, culture filtrates of all the Drechslera species significantly declined shoot biomass over the control by 34 to $69 \%$ and 69 to $82 \%$ when applied in a diluted and original concentration, respectively (Table 1). These findings agree with the results of some earlier studies where culture filtrates of other Drechslera species exhibited herbicidal activity against weeds (Kastanias and Tokousbalides, 2000; Evidente et al., 2005; 2006a). Various herbicidal constituents have been identified from different Drechslera species. Sugawara et al. (1987) isolated ophiobolin I from Drechslera maydis and $D$. sorghicola, which exhibited herbicidal activity. Kastanias and Tokousbalides (2000) isolated pyrenophorol from a $D$. avenae pathotype that exhibited herbicidal potential against Avena sterilis L. Evidente et al. (2005) reported that drazepinone, a trisubstituted tetrahydronaphthofuroazepinone from $D$. siccans, exhibited herbicidal activity against monocot weeds. In another study, Evidente et al. (2006b) identified four herbicidal constituents from D. gigantea, viz. ophiobolin A, 6-epi-ophiobolin A, anhydro-6-epi-ophiobolin A, and ophiobolin I, which were very effective against several grass and broadleaf weeds.

Root length was highly susceptible to various treatments. Both the original and diluted growth media significantly reduced root length by 31 and $24 \%$, respectively. Original and diluted culture filtrates of all four Drechslera species significantly reduced root length by 90 to $92 \%$ and 84 to $90 \%$, respectively, as compared to the control. Root biomass was reduced by 13 and $10 \%$ due to original and diluted growth media, but the effect was not significant. The adverse effect of all the fungal culture filtrate treatments on root biomass was significant. There was a 67 to $83 \%$ and 32 to $58 \%$ reduction in root biomass due to original and diluted culture filtrates of various Drechslera species, respectively, as compared to the control (Table 1).

\section{Pot trials}

Culture filtrates of various Drechslera species reduced shoot length of 1-wk and 2-wk old seedlings by 2 to $26 \%$ and 6 to $33 \%$, respectively. The effect of $D$. australiensis culture filtrates was significant in the 1-wk old plant treatment, while the effect of D. biseptata and $D$. hawaiiensis was significant in the 2-wk old plant treatment (Figure 1A). All foliar spray applications reduced shoot dry biomass to variable extents. In the 1-wk old plant treatment, foliar spray of $D$. australiensis and $D$. biseptata culture filtrates significantly reduced shoot biomass by 43 and $55 \%$, respectively. The effect of culture filtrates of the other two fungal species was not significant. Twoweek-old plants were more susceptible to foliar spray application than 1-wk old plants. In 2-wk old plants, different fungal culture filtrate treatments reduced shoot biomass by 27 to $65 \%$ (Figure 1B).

In general, the effect of foliar spray on root length was not very pronounced. Only $D$. hawaiiensis filtrates significantly reduced root length by $56 \%$ in 1 -wk old plants. The effect of all other treatments on this root growth parameter was not significant (Figure 1C). Root dry biomass showed a more pronounced response to foliar spray application than root length. There was 13 to $62 \%$ and 27 to $76 \%$ in 1-wk and 2-wk old plants, respectively, (Figure 1D).
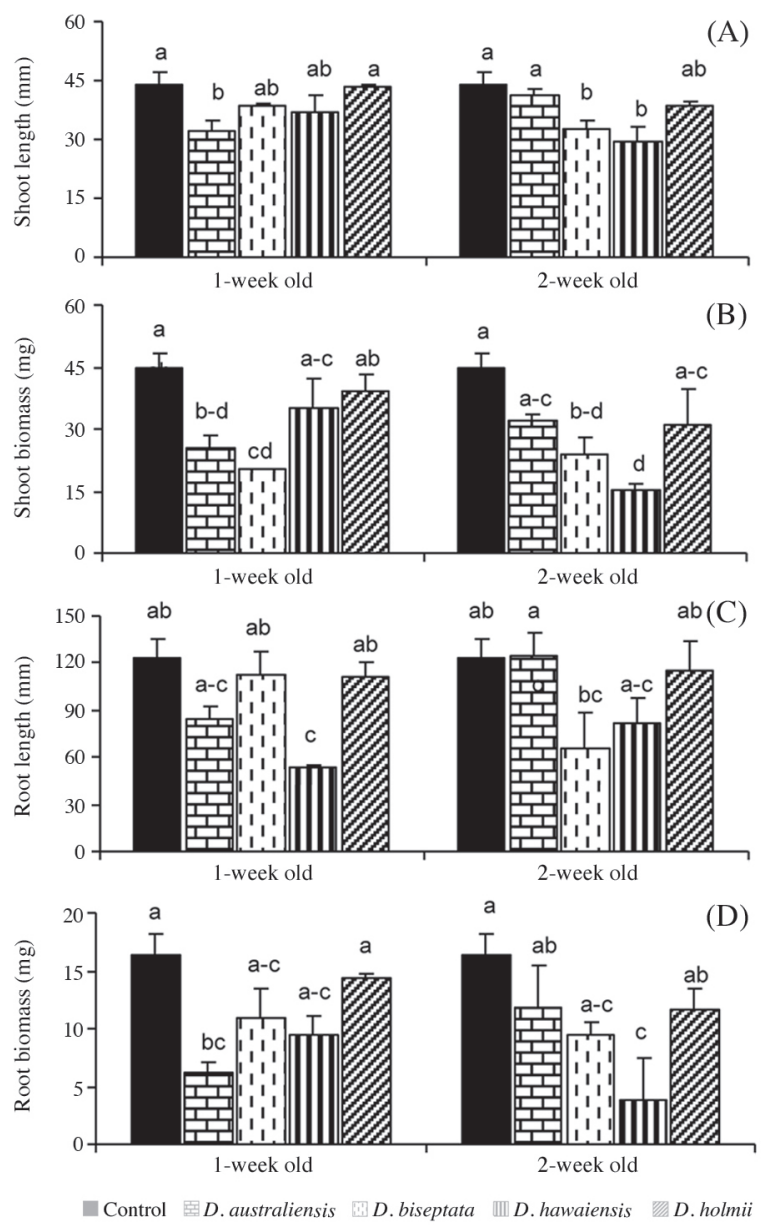

Vertical bars show standard errors of means of three replicates. Values with different letters show significant differences as determined by Duncan's Multiple Range Test at $\mathrm{P} \leq 0.05$.

Figure 1. Effect of foliar spray of four species of Drechslera culture filtrates on growth of 1-wk and 2-wk old parthenium plants. 


\section{CONCLUSIONS}

The present study concludes that culture filtrates of the four tested Drechslera species are very effective for parthenium weed management. Further studies are required to isolate and identify the potential herbicidal constituents present in these fungal culture filtrates.

\section{Potencial herbicida de filtrados de cultivo de} Drechslera spp. contra Parthenium hysterophorus L. Se investigó la actividad herbicida de filtrados de cultivos de cuatro especies de Drechslera spp., i.e. D. australiensis (Bugnic.) Subram. \& B.L. Jain, D. biseptata (Sacc. \& Roum.) M.J. Richardson \& E.M. Fraser, D. hawaiiensis Bugnic. ex M.B. Ellis, and D. holmii (Luttr.) Subram. \& P.C. Jain, preparados en caldo de extracto de malta contra la maleza Parthenium hysterophorus L. en bioensayos de laboratorio y en macetas. En los bioensayos de laboratorio se estudió el efecto de filtrado de cultivo original (100\%) y diluido (50\%) de Drechslera spp. en la germinación y crecimiento de plántulas de parthenium en placas Petri de $90 \mathrm{~mm}$. El filtrado de cultivo original de las cuatro especies Drechslera redujo significativamente germinación, longitud de brote, biomasa fresca de brote, longitud de raíz, y biomasa fresca de raíz de plántulas de parthenium en $43-77 \%$, $77-82 \%, 69-82 \%$, 90-92\% y $67-$ $83 \%$, respectivamente, comparado con control. En ensayos en maceta, la aplicación foliar de filtrados de cultivos fúngicos originales se realizó en plántulas de parthenium de 1 y 2 semanas de edad. Filtrados de cultivo de todas las especies, excepto $D$. holmii, redujeron marcadamente el peso seco de brote de parthenium. Plantas de 2 semanas de edad fueron más susceptibles a aspersión foliar que aquellas de 1 semana. Hubo reducción de $13-55 \%$ y $28-$ $65 \%$ en peso seco de brote de plantas de 1 y 2 semanas de edad, respectivamente, debido a filtrado de cultivo de diversas Drechslera. El presente estudio concluyó que los filtrados de cultivo de Drechslera spp. pueden usarse como herbicidas alternativos para el manejo de parthenium.

Palabras clave: Drechslera spp., filtrados de cultivo fúngico, herbicidas naturales, Parthenium hysterophorus.

\section{LITERATURE CITED}

Abbas, .H.K., T. Tanaka, S.O. Duke, and C.D. Boyette. 1995. Susceptibility of various crops and weed species to ALL-toxin, a natural herbicide. Weed Technology 9:125-130.

Chandras, G.S., and V.D. Vartak. 1970. Symposium on problems caused by Parthenium hysterophorus in Maharashtra Region, India. PANS 16:212-214.

Evidente, A., A. Andolfi, A. Cimmino, M. Vurro, M. Fracchiolla, and R. Charudattan. 2006b. Herbicidal potential of ophiobolins produced by Drechslera gigantean. Journal of Agriculture and Food Chemistry 54:1779-1783.

Evidente, A., A. Andolfi, M. Vurro, M.C. Zonno, and A. Motta. 2000. Trans-4 aminoproline, a phytotoxic metabolite with herbicidal activity produced by Ascochyta caulina. Phytochemistry 53:231237.
Evidente, A., A. Andolfi, M. Vurro, M.C. Zonno, and A. Motta. 2005. Drazepinone, a trisubstituted tetrahydronaphthofuroazepinone with herbicidal activity produced by Drechslera siccans. Phytochemistry 66:715-721.

Evidente, A., A. Cimmino, M. Vurro, M. Fracchiolla, R. Charudattan, and A. Motta. 2006a. Ophiobolin E and 8-epi-ophiobolin J produced by Drechslera gigantea, a potential mycoherbicide of weedy grasses. Phytochemistry 67:2281-2287.

Javaid, A. 2007. Efficacy of some chemical herbicides against Parthenium hysterophorus L. Pakistan Journal Weed Science Research 13:93-98.

Javaid, A. 2010. Herbicidal potential of allelopathic plants and fungi against Parthenium hysterophorus - a review. Allelopathy Journal 25:331-344.

Javaid, A., and H. Adrees. 2009. Parthenium management by cultural filtrates of phytopathogenic fungi. Natural Product Research 23:1541-1551

Javaid, A., and S. Ali. 2011a. Herbicidal activity of culture filtrates of Trichoderma spp. against two problematic weeds of wheat. Natural Product Research 25:730-740.

Javaid, A., and S. Ali. 2011b. Alternative management of a problematic weed of wheat Avena fatua L. by metabolites of Trichoderma. Chilean Journal of Agricultural Research 71:205211.

Javaid, A., and T. Anjum. 2005. Parthenium hysterophorus L. - A noxious alien weed. Pakistan Journal of Weed Science Research 11:171-177.

Javaid, A., and T. Riaz. 2007. Spread of aggressive alien weed parthenium hysterophorus L. in district Okara, Pakistan. Journal of Animal and Plant Sciences 17:59-60.

Javaid, A., S. Shafique, and S. Shafique. 2010. Herbicidal effects of extracts and residue incorporation of Datura metel against parthenium weed. Natural Product Research 24:1426-1437.

Javaid, A., S. Shafique, and S. Shafique 2011. Management of Parthenium hysterophorus (Asteraceae) by Withania somnifera (Solanaceae). Natural Product Research 25:407-416.

Kastanias, M.A., and M.C. Tokousbalides. 2000. Herbicidal potential of pyrenophorol isolated from a Drechslera avenae pathotype. Pest Management Science 56:227-232.

Mishra, J.S., and V.M. Bhan. 1994. Efficacy of sulphonyl urea herbicides against Parthenium hysterophorus. Weed News 1:16.

More, P.R., V.P. Vadlamudi, and M.I. Qureshi. 1982. Note on the toxicity of Parthenium hysterophorus in livestock. Indian Journal of Animal and Plant Sciences 52:456-457.

Nakajima, M., K. Itoi, T. Takamatsu, and T. Haneishi. 1989. Cornexistin: A new fungal metabolite with herbicidal activity. Journal of Antibiotic 42:1065-1072.

Neergaard, P. 1977. Seed pathology. Vol. 1. p. 839. The Gresham Press, Surrey, England.

Rabbani, N., R. Bajwa, and A. Javaid. 2011. Influence of culturing conditions on growth and sporulation of Drechslera hawaiiensis, the foliar blight pathogen of Marsilea minuta L. African Journal of Biotechnology 10:1863-1872.

Riaz, T., and A. Javaid. 2010. Prevalence of invasive parthenium weed in district Hafizabad, Pakistan. Journal of Animal and Plant Sciences 20:90-93.

Singh, H.P., D.R. Batish, and R.K. Kohli. 2003. Allelopathic interactions and allelochemicals: New possibilities for sustainable weed management. Critical Reviews in Plant Sciences 22:239311.

Singh, H.P., D.R. Batish, J.K. Pandher, and R.K. Kohli. 2005. Phytotoxic effects of Parthenium hysterophorus residues on three Brassica species. Weed Biology and Management 5:105-109.

Steel, R.G.D., and J.H. Torrie. 1980. Principles and procedures of statistics. A biometrical approach. 2nd ed. McGraw Hill Book, New York, USA.

Sugawara, F., G. Strobel, R.N. Strange, J.N. Siedow, G.D. Van Duyne, and J. Clardyv. 1987. Phytotoxins from the pathogenic fungi Drechslera maydis and Drechslera sorghicola. Proceedings of National Academy of Science USA 84:3081-3085. 